\title{
TRACE ELEMENT CONTENTS IN UNCULTIVATED SURFACE SOILS IN THE KAVALA AREA, NORTHERN GREECE
}

\author{
Papastergios G. ${ }^{1}$, Filippidis A. ${ }^{1}$, Christofides G. ${ }^{1}$, Kassoli-Fournaraki A. ${ }^{1}$, \\ Fernández-Turiel J. L. ${ }^{2}$, Georgakopoulos A. ${ }^{1}$, and Gimeno D. ${ }^{3}$ \\ ${ }^{1}$ Department of Mineralogy-Petrology-Economic Geology, School of Geology, Aristotle \\ University of Thessaloniki, 54124,Thessaloniki,gpapaste@geo.auth.gr \\ ${ }^{2}$ Institute of Earth Sciences "Jaume Almera”, Consejo Superior de Investigaciones Cientificas \\ (CSIC), Barcelona, Spain, jlfernandez@ija.csic.es \\ ${ }^{3}$ Department of Geochemistry, Petrology and Geological Exploration, University of Barcelona, \\ Spain,domingo@natura.geo.ub.es
}

\begin{abstract}
A total of 65 uncultivated surface soils samples from the area surrounding the city of Kavala, Northern Greece, was collected and analyzed for their abundance in 22 trace elements. The extraction of the elements from the $<200 \mu \mathrm{m}$ soil fraction was based on the digestion of $0.1 \mathrm{~g}$ of each sample with $2 \mathrm{ml} \mathrm{HNO}$. The analytical methods used were ICP-OES and ICP-MS and the elements analyzed were Ag, As, $\mathrm{B}, \mathrm{Ba}, \mathrm{Cd}, \mathrm{Co}, \mathrm{Cr}, \mathrm{Cs}, \mathrm{Cu}, \mathrm{Hg}, \mathrm{Mn}, \mathrm{Mo}, \mathrm{Ni}, \mathrm{Pb}, \mathrm{Sb}, \mathrm{Se}, \mathrm{Sn}, \mathrm{Sr}, \mathrm{Ti}, \mathrm{V}, \mathrm{W}$, and $\mathrm{Zn}$. The chemistry of the surrounding rocks and mineralizations has mainly affected the trace elements contents of the surface soils samples. The average elemental concentrations of the 65 uncultivated surface soil samples were compared with the average values for normal soils of the USA. Arsenic, $\mathrm{Pb}$, and $\mathrm{Zn}$ were found to be enriched in the surface soils of the present study by a factor of 7.6, 3.3, and 2.7, respectively, indicating that human activities have contributed to their enrichment, since these elements are strongly connected to the industrial and agricultural activities in the area. Key words: surface soil, trace elements, environmental research.
\end{abstract}

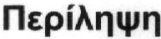

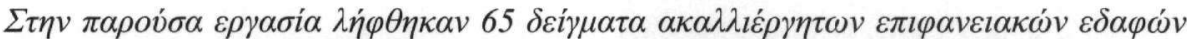

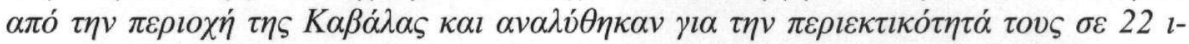

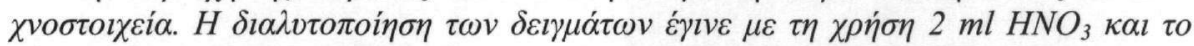

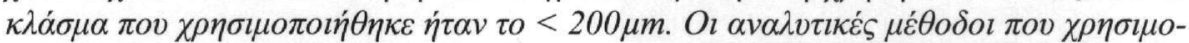

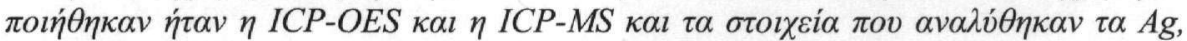
$\mathrm{As}, \mathrm{B}, \mathrm{Ba}, \mathrm{Cd}, \mathrm{Co}, \mathrm{Cr}, \mathrm{Cs}, \mathrm{Cu}, \mathrm{Hg}, \mathrm{Mn}, \mathrm{Mo}, \mathrm{Ni}, \mathrm{Pb}, \mathrm{Sb}, \mathrm{Se}, \mathrm{Sn}, \mathrm{Sr}, \mathrm{Ti}, \mathrm{V}, \mathrm{W}, \kappa \alpha \mathrm{Zn}$.

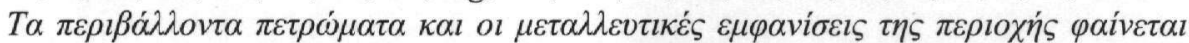

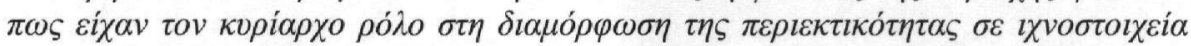

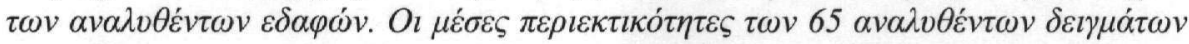

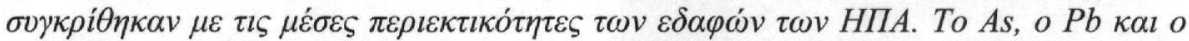

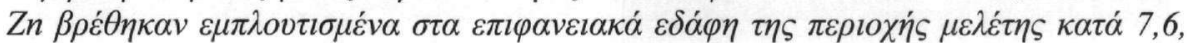




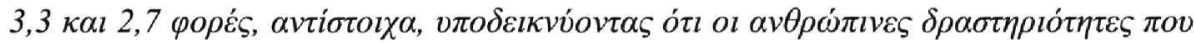

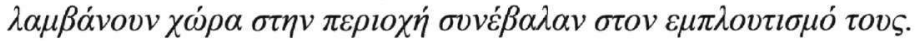

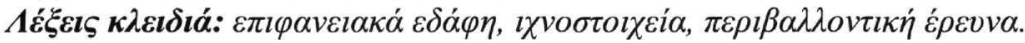

\section{Introduction}

Trace elements, especially trace metals, are considered to be one of the main sources of pollution in the environment because they lead to changes and to a degradation of the natural environment. Human activities mobilize and redistribute elements in the environment, often causing adverse effects. Both industry and agriculture have contributed significantly to the elevated concentrations of environmentally important trace elements through waste disposal, atmospheric deposition, fertilizer and pesticide use, and other means (Georgakopoulos et al. 1996, 2001, 2002, Hesterberg 1998, Kabata-Pendias and Pendias 2001, Grigoriadou et al. 2004, Cui et al. 2005).

Sediments and soils are the principal sinks for trace metals. The study of the distribution of metals in sediments and soils is very important from an environmental point of view, because they concentrate metals and represent an appropriate medium to monitor contamination (Georgakopoulos et al. 1996, 2001, 2002, Kabata-Pendias and Pendias 2001, Sarkar et al. 2004, Kelepertsis et al. 2006). Trace metals environmental importance is closely related to their accumulation and potential toxicity. High levels of trace metals in sediments and soils may result in an increased metal uptake by crops and vegetables which, in turn, may have a negative effect on animals and human health (Kabata-Pendias and Pendias 2001, Cui et al. 2005).

The scope of this study was to conduct a first assessment on the geochemical fingerprint of the surface soils of Kavala area.

\subsection{Study area}

The study area (Fig. 1) is located around the city of Kavala and its industrial zone, and lies between latitudes $40^{\circ} 48^{\prime}$ and $41^{\circ} 06^{\prime}$ and longitudes $24^{\circ} 15^{\prime}$ and $24^{\circ} 40^{\prime}$. The land-uses in the area of interest are mainly agricultural, industrial and residential. The main industrial activities are the Phosphoric Fertilizers Industry (P.F.I.), the Kavala Oil Land Facilities (K.O.L.F.) and some medium-size enterprises that exploit and commerce industrial rocks (marbles). The climate shows central European features with cold winters and warm summers. The annual average precipitation ranges from 500 to $700 \mathrm{~mm}$. The mean temperature is $4.0^{\circ} \mathrm{C}$ in January and $24.5^{\circ} \mathrm{C}$ in July and the prevailing wind is from the SE (H.N.M.S., 1978; Petalas et al., 2004).

\subsection{Geological setting}

The study area is a part of the Rhodope massif and it consists of metamorphic and plutoniceruptive rocks (Fig. 1) with an extent of about $24 \mathrm{~km}$ from east to west. The main rock types in the area are: a) gneisses, schists and amphibolites (Permian-Eocene), b) marbles (Permian-Eocene), c) granitic and granodioritic rocks (Cretaceous-Oligocene), and d) sedimentary deposits (MioceneHolocene). The intense plutonism of the Rhodope is represented by granites, granodiorites, monzonites, quartz monzonites and diorites of Eocene, Oligocene, and Miocene age (Kilias and Mountrakis 1998, Christofides et al. 2001, Rondoyanni et al. 2004). Additionally, the PyriteBlende-Galena (PBG), $\mathrm{Au}, \mathrm{Cu}, \mathrm{Mn}$, and $\mathrm{Fe}$ mineralizations and ore deposits are widespread in the study area (Maratos and Andronopoulos 1966, Filippidis et al. 1996, Vavelidis et al. 1996, 1997). 


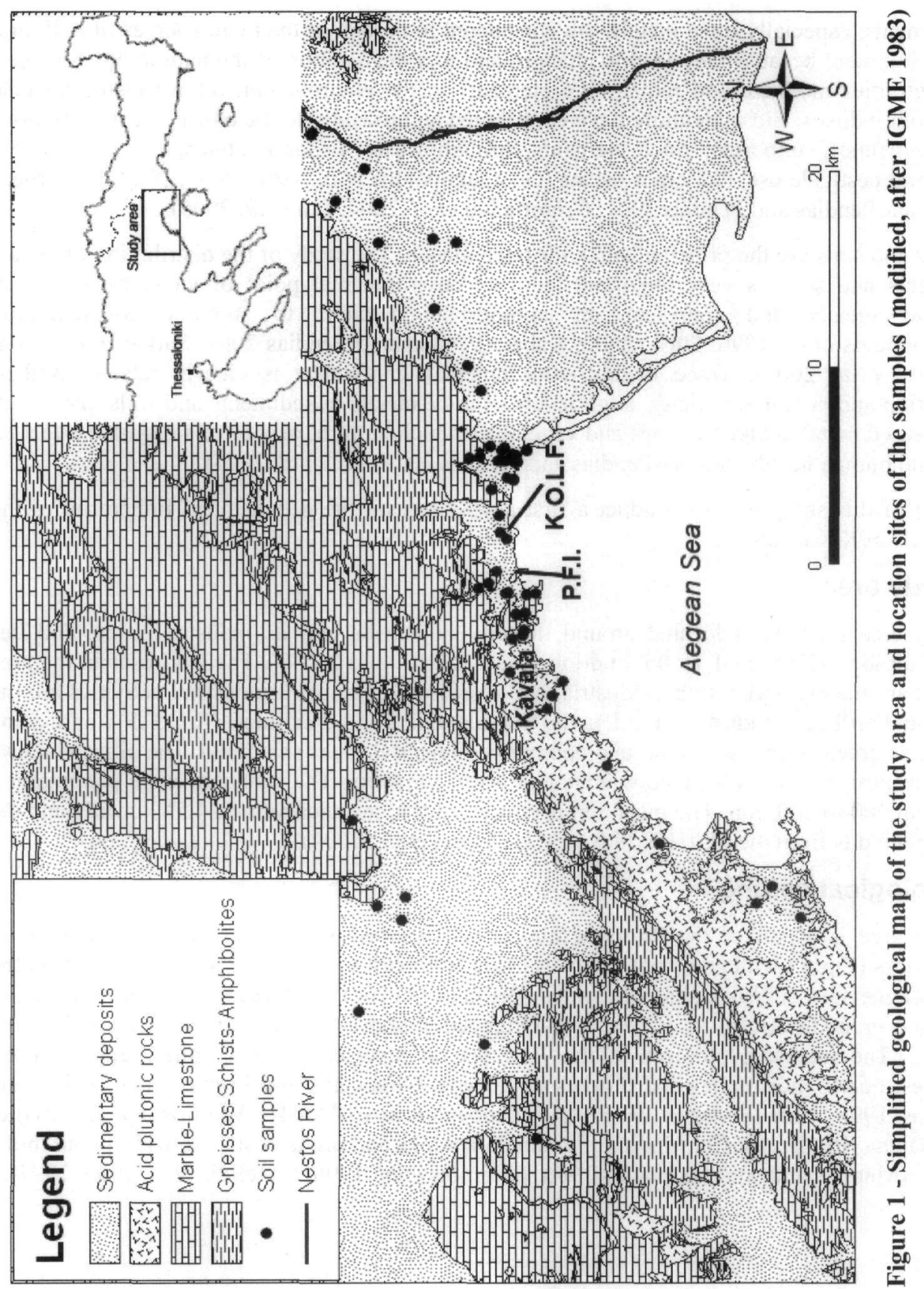




\section{Methodology}

\subsection{Sampling}

In total, 65 uncultivated surface soil $(0-20 \mathrm{~cm})$ samples were collected between 2-11-2002 and 171-2003 (Fig. 1). Uncultivated surface soil was selected because it is very sensible to anthropogenic influences. This kind of samples is well suited for gaining information on the long-term impact of trace metals accumulation (Ramsey 1997, Fernández-Turiel et al. 2001, Chen 2001, KabataPendias and Pendias 2001).

\subsection{Sample preparation}

All samples were dried in an oven at $40^{\circ} \mathrm{C}$. After sieving all samples, the $<200 \mu \mathrm{m}$ fraction was used since the environmentally available trace elements mainly remain in this fraction (FernándezTuriel et al. 2001, Kabata-Pendias and Pendias 2001, Lucho-Constantino et al. 2005).

The elements analyzed were extracted by a leaching procedure using analytical quality $\mathrm{HNO}_{3}$ (Papastergios et al. 2004, 2006). The $\mathrm{HNO}_{3}$ extraction procedure is a very strong acid digestion that puts in solution almost all elements that could become "environmentally available" (Pickering 1986, Walsh et al. 1997, Quevauviller 2002, Sastre et al. 2002). Analytical grade $\mathrm{HNO}_{3}$ has been selected in order to work with extreme analytical conditions, and maintain, at the same time, the compatibility of the leachate with the input solution in Inductively Coupled Plasma-Mass Spectrometry (ICP-MS) and Inductively Coupled Plasma-Optical Emission Spectrometry (ICP$\mathrm{OES})$ (direct determination after dilution).

In the present work, a split of $0.1 \mathrm{~g}$ of each sample was placed into $14 \mathrm{~mm}$ diameter polyethylene tubes. Two $\mathrm{ml}$ of $\mathrm{HNO}_{3}$ were added. All samples were placed in a rotary shaker for $24 \mathrm{~h}$. After the extraction procedure, the solution was filtered (Schleicher and Schmell 5892 white ribbon, ash-less, filter paper circles of $125 \mathrm{~mm}$ diameter) in $100 \mathrm{ml}$ volume flasks. The volume flasks were made up volume with Milli-Q type purified water of $18.2 \mathrm{M} \Omega / \mathrm{cm}$. The final solution was placed in HDPE (high-density polyethylene) bottles, labeled, and stored in dark at $4{ }^{\circ} \mathrm{C}$ until analysis (Papastergios et al. 2004, 2006).

\subsection{Analytical methods: ICP-OES and ICP-MS analyses}

The 22 trace elements analyzed were $\mathrm{Ag}, \mathrm{As}, \mathrm{B}, \mathrm{Ba}, \mathrm{Cd}, \mathrm{Co}, \mathrm{Cr}, \mathrm{Cs}, \mathrm{Cu}, \mathrm{Hg}, \mathrm{Mn}, \mathrm{Mo}, \mathrm{Ni}, \mathrm{Pb}, \mathrm{Sb}$, $\mathrm{Se}, \mathrm{Sn}, \mathrm{Sr}, \mathrm{Ti}, \mathrm{V}, \mathrm{W}$, and, $\mathrm{Zn}$ and the analytical methods used were Inductively Coupled PlasmaOptical Emission Spectrometry (ICP-OES) and Inductively Coupled Plasma-Mass Spectrometry (ICP-MS). A PERKIN ELMER OPTIMA 3200RL with a PERKIN ELMER Autosampler AS-90+ was used for the ICP-OES analyses, while a PERKIN ELMER SCIEX ELAN 6000 with a PERKIN ELMER AS-91 automatic sampler was used for the ICP-MS analyses. The analyses were performed at the Faculty of Geology of the University of Barcelona, the SCT - UB (Scientific Technical Services of the University of Barcelona), and ICTJA - CSIC (Institute of Earth sciences "Jaume Almera" - Spanish Council for Scientific Research), Barcelona (Spain). For reasons of quality control, the analytical repeatability, the extraction procedure repeatability, and the extraction procedure recovery were calculated. All three factors were satisfactory for the work objectives (Papastergios et al. 2004, 2006).

\section{Results and discussion}

The average, minimum and maximum elemental concentrations for the trace elements of all the samples in the present study are shown in Table 1 (for the calculation of the averages, less than detection limit values were replaced with half the detection limit value of each element).

Manganese ( $524 \mathrm{mg} \mathrm{kg}^{-1}$ ) has the largest average concentration, and is followed, in decreasing order, by Zn (148 $\left.\mathrm{mg} \mathrm{kg}^{-1}\right), \mathrm{Ba}\left(97 \mathrm{mg} \mathrm{kg}^{-1}\right)$, Ti (75 $\left.\mathrm{mg} \mathrm{kg}^{-1}\right), \mathrm{Pb}\left(62 \mathrm{mg} \mathrm{kg}^{-1}\right)$, and As $\left(55 \mathrm{mg} \mathrm{kg}^{-1}\right)$. 
The rest of the trace elements have average concentrations below $50 \mathrm{mg} \mathrm{kg}^{-1}$, with $\mathrm{Sr}\left(36 \mathrm{mg} \mathrm{kg}^{-1}\right)$ being the highest and $\mathrm{Hg}\left(0.1 \mathrm{mg} \mathrm{kg}^{-1}\right)$ the lowest. The concentration values for the majority of the trace elements were near expected averages, taking into account the geological setting, and the mineralizations of the study area (Filippidis et al. 1996). Some elements, i.e. As, $\mathrm{Pb}$, and $\mathrm{Zn}$ are found with average values, as well as, maximum values that seem to be elevated. However, a study conducted by Kelepertsis et al. (2006) in a similar, nearby area (Stratoni-Chalkidiki Peninsula) found that soils near PBG sulfide mineralizations could have much higher concentrations (e.g., $\mathrm{Pb}$ had a mean of $895 \mathrm{mg} \mathrm{kg}^{-1}$, As $364 \mathrm{mg} \mathrm{kg}^{-1}$ and $\mathrm{Zn} 654 \mathrm{mg} \mathrm{kg}^{-1}$ ). An interesting fact though, is that the former elements in our work are found with their largest values in the vicinity of the Kavala city industrial zone whereas, in the study of Kelepertsis et al. (2006) the largest values are found near the ore bodies of their study area. This could possibly mean that the human activities taking place in our study area have contributed, at least partly, in these elevated values, especially since all these elements are strongly connected with the production and usage of these elements by such industries (Adriano 1986, Hesterberg 1998, Kabata-Pendias and Pendias 2001, Cui et al. 2005).

Table 1 - The average, minimum and maximum elemental concentrations for the trace elements of the studied soil samples (in $\mathrm{mg} \mathrm{kg}^{-1}$ ) and the comparison between the average values of the present work and Adriano (1986)

\begin{tabular}{|c|c|c|c|c|c|}
\hline Element & min & $\mathbf{m a x}$ & $\begin{array}{c}\text { average } \\
\text { (this work) }\end{array}$ & $\begin{array}{c}\text { USA normal } \\
\text { soils (Adriano, } \\
\mathbf{1 9 8 6})\end{array}$ & $\begin{array}{c}\text { Enrichment Factor } \\
\text { average (this work) } \\
\text { USA normal soils }\end{array}$ \\
\hline $\mathbf{A g}$ & $<0.01$ & 9.3 & 0.6 & 0.7 & 0.9 \\
\hline $\mathbf{A s}$ & 1.4 & 1634.5 & 55.1 & 7.2 & 7.6 \\
\hline $\mathbf{B}$ & 0.4 & 84.0 & 8.0 & 30 & 0.3 \\
\hline $\mathbf{B a}$ & 15.9 & 323.8 & 97.2 & 440.0 & 0.2 \\
\hline $\mathbf{C d}$ & $<0.01$ & 3.4 & 0.6 & 0.35 & 1.7 \\
\hline $\mathbf{C o}$ & 1.0 & 39.4 & 6.8 & 6.7 & 1.0 \\
\hline $\mathbf{C r}$ & 1.0 & 74.3 & 16.1 & 40 & 0.4 \\
\hline $\mathbf{C s}$ & 0.3 & 8.7 & 1.6 & 4 & 0.4 \\
\hline $\mathbf{C u}$ & 3.2 & 184.3 & 22.3 & 30 & 0.7 \\
\hline $\mathbf{H g}$ & $<0.01$ & 0.5 & 0.1 & 0.11 & 0.6 \\
\hline $\mathbf{M n}$ & 13.1 & 2111.2 & 524.2 & 560.0 & 0.9 \\
\hline $\mathbf{M o}$ & $<0.01$ & 6.7 & 0.3 & 0.97 & 0.3 \\
\hline $\mathbf{N i}$ & 2.3 & 78.7 & 14.9 & 20.0 & 0.7 \\
\hline $\mathbf{P b}$ & 3.9 & 873.1 & 62.4 & 19 & 3.3 \\
\hline $\mathbf{S b}$ & $<0.01$ & 2.0 & 0.3 & 0.48 & 0.6 \\
\hline $\mathbf{S e}$ & 0.6 & 2.8 & 0.8 & 0.4 & 2.0 \\
\hline $\mathbf{S n}$ & 0.1 & 4.3 & 0.4 & 0.9 & 0.5 \\
\hline $\mathbf{S r}$ & 4.4 & 787.3 & 35.6 & 67.0 & 0.5 \\
\hline $\mathbf{T i}$ & 2.7 & 382.8 & 74.5 & 2400.0 & $<0.01$ \\
\hline $\mathbf{V}$ & 2.4 & 78.1 & 18.4 & 58.0 & 0.3 \\
\hline $\mathbf{W}$ & $<0.01$ & 8.7 & 0.4 & 1.5 & 2.7 \\
\hline $\mathbf{Z n}$ & 13.4 & 5416.1 & 147.7 & 54.0 & \\
\hline & & & & & \\
\hline
\end{tabular}

In an effort to further investigate the status of the topsoils in the Kavala area, the concentrations of the present work were compared with those cited by Adriano (1986) for normal soils of the USA, and their enrichment factors were calculated (Table 1). 
The results indicate that as is enriched, in regard with its respective concentration for normal soils of the USA, almost 7.6 times, while the enrichment factors of $\mathrm{Pb}$ and $\mathrm{Zn}$ are 3.3 and 2.7, respectively. Other elements found relatively enriched are $\mathrm{Cd}$ (2.0 times), and $\mathrm{Se}$ (1.7 times), while the rest of the elements have enrichment factors around 1 or lowers (depletion). The reason for the rest of the elements having enrichment factors around 1 or lower could be attributed to either the fact that these elements have indeed lower concentrations, in total, in the topsoils of the Kavala area than those of the USA, or to the extraction method applied for this work.

\section{Conclusions}

The results indicate that the procedures of pedogenesis and erosion of the surrounding rocks of the study area have played an important role on the geochemical fingerprint of the surface soils studied in the present work. The majority of the elements are found in the samples of the present study with concentrations within normal ranges. However, some extreme values are noticed for As, $\mathrm{Pb}$, and $\mathrm{Zn}$. The comparison between the average values of the present study and the values for the USA normal soils indicates that the former elements ( $\mathrm{As}, \mathrm{Pb}$ and $\mathrm{Zn}$ ) are found enriched (7.6, 3.3 and 2.7 times, respectively). Furthermore, these elements are found at their highest concentrations in the vicinity of the industrial zone of Kavala. The human activities have, also contributed to the enrichment of these elements, since they are strongly connected with the industrial and agricultural activities in the area.

\section{Acknowledgments}

Georgios Papastergios would like to acknowledge the support of the Greek State Scholarships Foundation (IKY).

\section{References}

Adriano, D.C., 1986. Trace elements in the terrestrial environment, Springer-Verlag, New York, $533 \mathrm{pp}$.

Chen, M., 2001. Arsenic Background Concentrations in Florida, U.S.A. Surface Soils: Determination and Interpretation. Environmental Forensics, 2, 117-126.

Christofides, G., Koroneos, A., Soldatos, T., Eleftheriadis, G., and Kilias, A., 2001. Eocene magmatism (Sithonia and Elatia plutons) in the Internal Hellenides and implications for Eocene-Miocene geological evolution of the Rhodope Massif (Northern Greece), Acta Vulcanologica, 13(1-2), 73-89.

Cui, Y.-J., Zhai, R.-H., Huang, Y.-Z., Qiu, Y., and Liang, J.-Z., 2005. Exposure to metal mixtures and human health impacts in a contaminated area in Nanning, China, Environment International, 31, 784-790.

Hesterberg, D., 1998. Biogeochemical cycles and processes leading to changes in mobility of chemicals in soils, Agriculture, Ecosystems and Environment, 67, 121-133.

H.N.M.S. (Hellenic National Meteorological Service), 1978. Climatic data of the Greek network, period $1930-1975,100 \mathrm{pp}$. (in Greek)

Fernández-Turiel, J.L., Aceñolaza, P., Medina, M.E., Llorens, J.F., and Sardi, F., 2001. Assessment of a smelter impact area using surface soils and plants, Environ. Geochem. Health, 23, 65-78.

Filippidis, A., Georgakopoulos, A. Kassoli-Fournaraki, A., Misaelides, P., Yiakkoupis, P., and Broussoulis, J., 1996. Trace element contents in composite samples of three lignite seams from the central part of the Drama lignite deposit, Macedonia, Greece, International Journal of Coal Geology, 29, 219-234. 
Georgakopoulos, A., Fernández-Turiel, J.L., Christanis, K., Kalaitzidis, S., Kassoli-Fournaraki, A., Llorens, J.F., Filippidis, A. and Gimeno, D., 2001. The Drama basin water: quality and peat/lignite interaction. Environ. Geol., 41,121-127.

Georgakopoulos, A., Fernández-Turiel, J.L., and Gimeno, D., 2002. Influence of oil facilities in seawater quality: Trace element distribution near Kavala, Northern Aegean Sea (Greece), 6th Pan-Hellenic Geographical Congress of the Hellenic Geographical Society, Thessaloniki, 3-6 October 2002, II, 343-348.

Georgakopoulos, A., Filippidis, A., Kassoli-Fournaraki, A., Fernández-Turiel, J.L., and Llorens, J.F., 1996. The content of some trace elements in surface soils and fly ash of Ptolemais lignite basin Macedonia, Greece, Third International Conference on Environmental Pollution, Thessaloniki, 16-20 September, Proceedings, 114-118.

Grigoriadou, A., Georgakopoulos, A., Schwarzbauer, J., Kassoli-Fournaraki, A., Filippidis, A. and Papastergios, G., 2004. Organic pollutants in the industrial area east of Kavala, Northern Greece, Bulletin of the Geological Society of Greece vol. XXXVI, 2004, Proceedings of the 10th International Congress, Thessaloniki, April 2004, 1, 254-262.

Institute of Geology and Mineral Exploration (IGME), 1983. Geological map of Greece, scale: 1:500.000, second edition.

Kabata-Pendias, A., and Pendias, H., 2001. Trace Elements in Soils and Plants, $3^{\text {rd }}$ Edition, CRC Press, New York, 413pp.

Kelepertsis, A., Argyraki, A., and Alexakis, D., 2006. Multivariate statistics and spatial distribution of geochemical data for assessing soil contamination by potentially toxic elements in the mining area of Stratoni, north Greece, Geochemistry: Exploration, Environment, Analysis, 6, 349-355.

Kilias, A.A., and Mountrakis, D.M., 1998. Tertiary extension of the Rhodope massif associated with granite emplacement (Northern Greece), Acta Vulcanologica, 10(2), 331-337.

Lucho-Constantino, C.A., Álvarez-Suárez, M., Beltrán-Hernández, R.I., Prieto-García, F., and Poggi-Varaldo, H.M., 2005. A multivariate analysis of the accumulation and fractionation of major and trace elements in agricultural soils in Hidalgo State, Mexico irrigated with raw wastewater, Environment International, (31), 313-323.

Maratos, G., and Andronopoulos, B., 1966. Ore deposits and mineralizations map of the area between River Evros and River Axios, scale 1:400.000. (in Greek)

Papastergios, G., Georgakopoulos, A., Fernández -Turiel, J.L., Gimeno, D., Filippidis, A., Kassoli-Fournaraki, A., and Grigoriadou, A., 2004. Heavy Metals and Toxic Trace elements contents in selected areas of the Kavala Prefecture, Northern Greece, Bulletin of the Geological Society of Greece vol. XXXVI, 2004, Proceedings of the 10th International Congress, Thessaloniki, April 2004,.1, 263-272.

Papastergios, G., Georgakopoulos, A., Fernández-Turiel, J.L., Gimeno, D., Vouvalidis, K., and Kapetanios, C., 2006. The geomorphic control and the environmental impact of geochemical processes in the Pangeon Mountain area, Northern Greece, $V I^{\text {th }}$ International Scientific Conference, Modern Management of Mine Producing, Geology and Environmental Protection (SGEM), II, 75-82pp, 12-16 June 2006, Bulgaria.

Petalas, C., Pliakas, F., Diamantis, I., and Kallioras, A., 2004. Study of the distribution of precipitation in District of Eastern Macedonia and Thrace for the Period 1964-1998, Bulletin of the Geological Society of Greece vol. XXXVI, 2004, Proceedings of the 10th International Congress, Thessaloniki, April 2004, 2, 1054-1063. (in Greek) 
Pickering, W.F., 1986. Metal ion speciation - Soils and sediments (a review),Ore Geology Reviews 1, Elsevier Science Publishers, Amsterdam, 83-146 pp.

Quevauviller, $\mathrm{Ph} ., 2002$. Operationally defined extraction procedures for soil and sediment analysis. Part 3: New CRMs for trace-element extractable contents, Trends Anal. Chem., 21(11), 774-785.

Ramsey, M.H., 1997. Sampling and sampling preparation. In: Modern Analytical Geochemistry. An introduction to Quantitative Chemical Analysis Techniques for Earth, Environmental and Materials Scientists, Gill, R., (Editor), Pearson Education, England, 329pp.

Rondoyanni, Th., Georgiou, Ch., Galanakis, D., and Kourouzidis, M., 2004. Evidences of active faulting in Thrace region (north-eastern Greece), Bulletin of the Geological Society of Greece vol. XXXVI, 2004, Proceedings of the 10th International Congress, Thessaloniki, April 2004, 41: 1671-1678.

Sarkar, S.k., Frančišković-Bilinski, S., Bhattacharya, A., Saha M., and Bilinski, H., 2004. Levels of elements in the surficial estuarine sediments of the Hugli River, northeast India and their environmental implications, Environment International, 30, 1089-1098 .

Sastre, J., Sahuquillo, A., Vidal, M., and Rauret, G., 2002. Determination of $\mathrm{Cd}, \mathrm{Cu}, \mathrm{Pb}$ and $\mathrm{Zn}$ in environmental samples: microwave-assisted total digestion versus aqua regia and nitric acid extraction, Analytica Chimica Acta, 462, 59-72.

Vavelidis, M., Christofides, G., and Melfos, V., 1996. The Au-Ag bearing mineralization and placer gold of Palea Kavala (Macedonia, N. Greece), In V. Knežević and B. Krstić (eds), Terranes of Serbia, The formation of the geologic framework of Serbia and the adjacent regions, Belgrade 1996, 311-316pp.

Vavelidis, M., Melfos, V., and Eleftheriadis, G., 1997. Mineralogy and microthermometric investigations in the Au-bearing sulphide mineralization of Palea Kavala (Maedonia, Greece), Mineral Deposits, 343-346.

Walsh, J.N., Gill, R., and Thirwall, M.F., 1997. Dissolution procedures for geochemical and environmental samples. In R. Gill, (ed.), Modern Analytical Geochemistry. An introduction to Quantitative Chemical Analysis Techniques for Earth, Environmental and Materials Scientists, Pearson Education Limited, England, 329pp. 